\title{
Epidemiological pattern of tattoo skin disease: a potential general health indicator for cetaceans
}

\section{Marie-Françoise Van Bressem ${ }^{1, *}$, Koen Van Waerebeek ${ }^{1}$, Francisco Javier Aznar ${ }^{2}$, Juan Antonio Raga ${ }^{2}$, Paul D. Jepson ${ }^{3}$, Pádraig Duignan ${ }^{4}$, Rob Deaville ${ }^{3}$, Leonardo Flach ${ }^{5}$, Francisco Viddi ${ }^{6}$, John R. Baker ${ }^{7}$, Ana Paula Di Beneditto ${ }^{8}$, Mónica Echegaray ${ }^{9}$, Tilen Genov ${ }^{10}$, Julio Reyes ${ }^{9}$, Fernando Felix ${ }^{11}{ }^{\text {, Raquel Gaspar }}{ }^{12}$, Renata Ramos ${ }^{13}$, Vic Peddemors ${ }^{14}$, Gian Paolo Sanino ${ }^{15}$, Ursula Siebert ${ }^{16}$}

${ }^{1}$ Cetacean Conservation Medicine Group (CMED), CEPEC, Museo de Delfines, Pucusana, Lima 20, Peru

${ }^{2}$ Marine Zoology Unit, Cavanilles Institute of Biodiversity and Evolutionary Biology, University of Valencia, PO Box 22085, 46071 Valencia, Spain

${ }^{3}$ Institute of Zoology, Regent's Park, London NW1 4RY, UK

${ }^{4}$ Veterinary Laboratory Agency, Luddington, Warwickshire, CV37 9SJ, UK

${ }^{5}$ Projeto Boto Cinza-VALE, Rua Sta Terezinha, 531-90 Vila Muriqui, Mangaratiba, Rio de Janeiro 23860-000, Brazil

${ }^{6}$ Centro Ballena Azul, Valdivia, Chile and Graduate School of the Environment, Macquarie University, Sydney, New South Wales 2109, Australia

${ }^{7}$ Department of Veterinary Pathology, University of Liverpool, Veterinary Teaching Hospital, Leahurst, Chester High Road, Neston, Wirral, CH64 7TE, UK

${ }^{8}$ Universidade Estadual do Norte Fluminense-CBB, Laboratório de Ciências Ambientais, Av. A. Lamego, 2000-Campo dos Goytacazes, Rio de Janeiro 28013-602, Brazil

${ }^{9}$ Áreas Costeras y Recursos Marinos (ACOREMA), Calle San Francisco 253, 201-B, Pisco, Peru

${ }^{10}$ Morigenos - Marine Mammal Research and Conservation Society, Jarska cesta 36/a, 1000 Ljubljana, Slovenia

${ }^{11}$ Fundación Ecuatoriana para el Estudio de Mamíferos Marinos (FEMM), PO Box 09-01-11905, Guayaquil, Ecuador

${ }^{12}$ Gatty Marine Laboratory, University of St. Andrews, St. Andrews, Fife KY16 8LB, Scotland, UK

${ }^{13}$ Everest, Av. Nossa Senhora dos Navegantes, 675/1201, Enseada do Suá, Vitória, Espírito Santo 29056-900, Brazil

${ }^{14}$ School of Biological \& Conservation Sciences, University of KwaZulu-Natal, Durban 4000, South Africa

${ }^{15}$ Centre for Marine Mammal Research LEVIATHAN, Lo Beltrán 2251, CP 7640392, Vitacura, Santiago, Chile

${ }^{16}$ Forschungs- und Technologiezentrum Westküste, Christian-Albrechts-Universität Kiel, Hafentörn 1, 25761 Büsum, Germany

ABSTRACT: The presence of tattoo skin disease (TSD) was examined in 1392 free-ranging and dead odontocetes comprising 17 species from the Americas, Europe, South Africa, New Zealand and Greenland. We investigated whether TSD prevalence varied with sex, age and health status. TSD was encountered in cetaceans from the Pacific and Atlantic Oceans as well as in those from the North, Mediterranean and Tasman Seas. No clear patterns related to geography and host phylogeny were detected, except that prevalence of TSD in juveniles and, in 2 species (dusky dolphin Lagenorhynchus obscurus and Burmeister's porpoise Phocoena spinipinnis), in adults was remarkably high in samples from Peru. Environmental factors and virus properties may be responsible for this finding. Sex did not significantly influence TSD prevalence except in the case of Peruvian P. spinipinnis. Generally, there was a pattern of TSD increase in juveniles compared to calves, attributed to the loss of maternal immunity. Also, in most samples, juveniles seemed to have a higher probability of suffering TSD than adults, presumably because more adults had acquired active immunity following infection. This holo-endemic pattern was inverted in poor health short-beaked common dolphins Delphinus delphis and harbour porpoises Phocoena phocoena from the British Isles, and in Chilean dolphins Cephalorhynchus eutropia from Patagonia, where adults showed a higher TSD prevalence than juveniles. Very large tattoos were seen in some adult odontocetes from the SE Pacific, NE Atlantic and Portugal's Sado Estuary, which suggest impaired immune response. The epidemiological pattern of TSD may be an indicator of cetacean population health.

KEY WORDS: Tattoo skin disease $\cdot$ Poxviruses $\cdot$ Cetaceans $\cdot$ Epidemiology $\cdot$ Health status 


\section{INTRODUCTION}

Tattoo skin disease (TSD) in cetaceans is characterised by irregular, grey, black or yellowish, stippled skin lesions that may occur on any part of the body but show a preferential distribution depending on the species (Van Bressem \& Van Waerebeek 1996). With some experience, tattoo lesions (or 'tattoos') are readily distinguished macroscopically from other types of integument blemishes and scars. Individual tattoos may persist for months, or even years, and recur. They eventually heal and convert into light grey marks that may or may not have a darker outline and a darker centre (Van Bressem et al. 2003). TSD has been observed in several species of free-ranging odontocetes in the North Atlantic and eastern Pacific Oceans and in the Mediterranean Sea, as well as in captive common bottlenose dolphins Tursiops truncatus (see Van Bressem et al. 1999). It was also recently reported in an Alaskan bowhead whale Balaena mysticetus, though no images of the lesions were provided (Bracht et al. 2006). TSD is caused by poxviruses (Flom \& Houk 1979, Geraci et al. 1979, Van Bressem et al. 1993) that belong to a new genus of the subfamily Chordopoxvirinae (family Chordopoxviridae), but have a common, most immediate ancestor with terrestrial poxviruses of the genus Orthopoxvirus (Bracht et al. 2006). Poxviruses affecting Delphinidae and Phocoenidae belong to different species (Pearce et al. 2008). They are thought to induce humoral immunity that protects neonates and young calves from the disease (Smith et al. 1983, Van Bressem \& Van Waerebeek 1996, Van Bressem et al. 2006a). Published and unpublished observations of tattoo occurrence linked to age-growth data suggest that passive immunity in Peruvian dusky dolphins Lagenorhynchus obscurus and Burmeister's porpoises Phocoena spinipinnis as well as in T. truncatus from the Sado Estuary, Portugal, lasts at least until 6 to 9 mo of age (Van Bressem \& Van Waerebeek 1996, ChávezLisambart 1998, Van Bressem et al. 2003).

Though clinical and epidemiological data do not indicate that poxvirus infection induces a high mortality rate when endemic, it may kill neonates and calves without protective immunity and may affect host population dynamics (Van Bressem et al. 1999). TSD, for instance, may have contributed to the decline of Tursiops truncatus from the Sado Estuary by possibly affecting juvenile survival. Besides, the presence of very large tattoo lesions and their persistence (over 3 years) in adults were suggestive of immune deficiencies (Van Bressem et al. 2003). In search of a general epidemiological pattern of TSD and of the potential relation between health status and TSD epidemiology, we studied the occurrence of tattoo lesions in cetaceans from several ocean provinces, the results of which we present here.

\section{MATERIALS AND METHODS}

The presence of TSD was examined in 1392 individuals of 17 cetacean species from the Pacific, the Atlantic and the southwestern Indian Oceans, as well as from the North, Baltic, Mediterranean and Tasman Seas. Animals were free-ranging $(\mathrm{n}=468)$, had stranded $(\mathrm{n}=182)$, had died traumatic deaths $(\mathrm{n}=741)$ in fisheries interactions (most of them) and from interspecific aggression (a few) or died from an unknown cause $(\mathrm{n}=1)$ (Tables $1 \& 2)$.

The cetaceans studied occupied all types of habitat, ranging from inshore/estuarine (waters of the shallower parts of the continental shelf, including those semi-enclosed by land, near river estuaries and the entrance of fjords), neritic (continental shelf waters up to about $200 \mathrm{~m}$ depth) and oceanic (waters beyond the shelf with a depth greater than $200 \mathrm{~m}$ ) (Tables 1 \& 2). Populations that straddled 2 habitats were assigned to the habitat in which they spend most time. Raw data that led to previously published papers on the epidemiology of TSD in Peruvian small cetaceans (Van Bressem \& Van Waerebeek 1996) and Tursiops truncatus from the Sado Estuary (Van Bressem et al. 2003) were re-analysed.

Dead specimens. The majority of specimens examined died entangled in nets or stranded in the period 1984 to 2008 (Tables 1 \& 2). Condition varied from fresh to early decomposition and most had intact skin. The entire body surface was examined for tattoos. Several specimens were frozen before examination. Sexual maturity was determined directly from a macroscopic and/or histological examination of the genital tract and mammary glands or was inferred from standard body length and life history parameters for these populations (Collet \& Saint Girons 1984, Slooten 1991, Van Waerebeek 1992, Calzada 1995, Lockyer 1995, Reyes \& Van Waerebeek 1995, Peddemors 1999, Duignan et al. 2003). The age of some animals was determined by counting growth layer groups in teeth (Perrin \& Myrick 1980, Hohn et al. 1989, Slooten 1991, Duignan et al. 2003, P. J. Duignan \& C. Lockyer unpubl. data).

Free-ranging dolphins. Skin lesions in free-ranging Tursiops truncatus from Slovenia, Portugal and Peru, Guiana dolphins Sotalia guianensis from Brazil and Chilean dolphins Cephalorhynchus eutropia from northern Patagonia, Chile, were detected from photos taken during small-boat surveys (Reyes et al. 2002, Van Bressem et al. 2003, Viddi et al. 2005, Flach et al. 2008, Genov et al. 2008). Considering that in these animals generally only upper body parts were visible, the reported prevalences represent minimum values. Dolphins were individually identified from natural marks (Würsig \& Jefferson 1990). Maturity status (calf, juvenile, adult) was estimated from relative body size and 


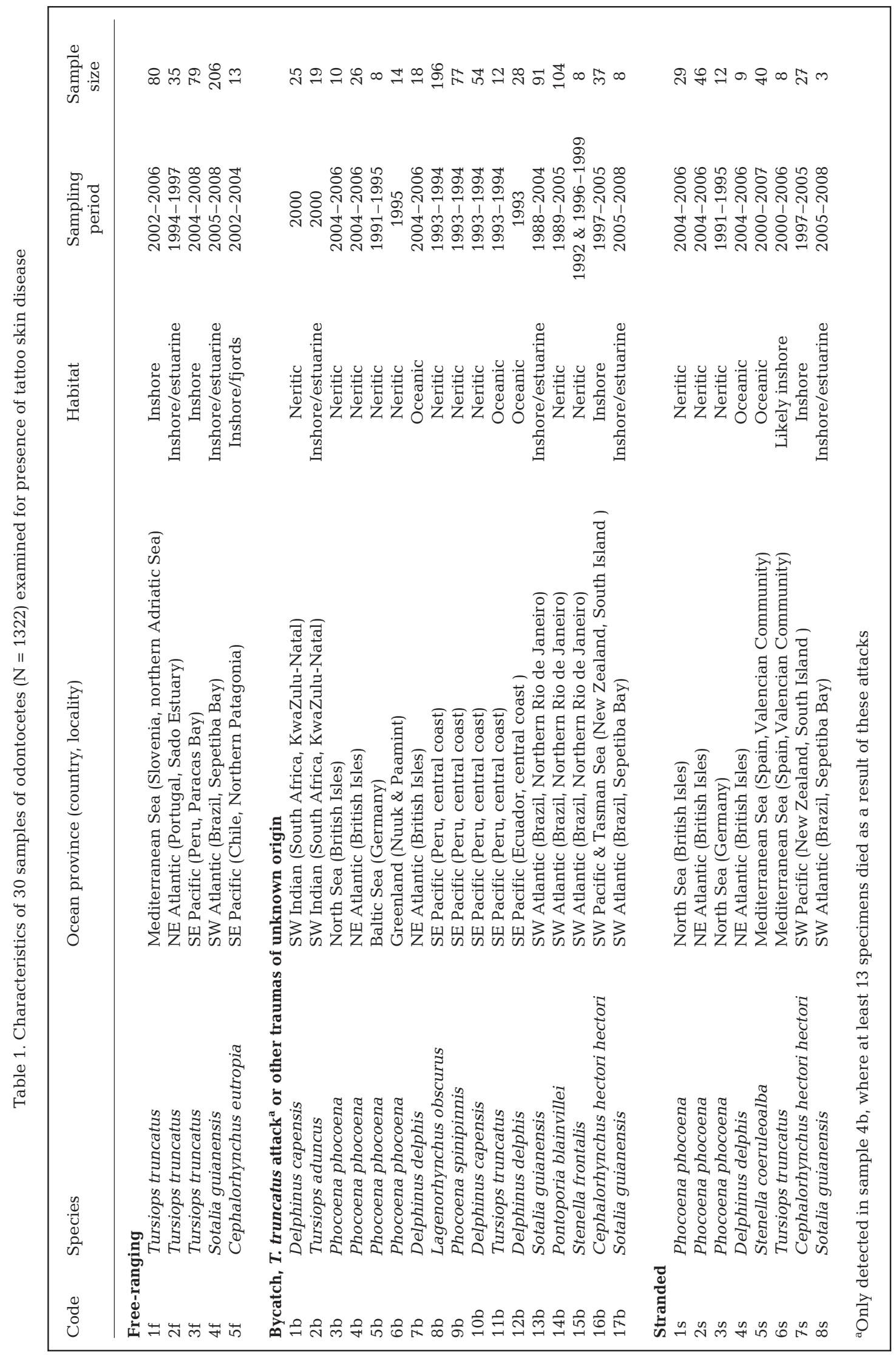


Table 2. Other records of tattoo skin disease in cetaceans. S: stranded; B: bycatch; F: free-ranging; N:P indicates negative and positive cases in the sample analyzed

\begin{tabular}{|c|c|c|c|c|c|}
\hline Species & Ocean province (country) & Habitat & Sampling period & Sample type & $\mathrm{N}: \mathrm{P}$ \\
\hline Hyperoodon ampullatus & North Sea (British Isles) & Oceanic & 2006 & $\mathrm{~S}$ & $0: 1$ \\
\hline Phocoena phocoena & NW Atlantic (Bay of Fundy, Canada) & Neritic & 1984 & $\mathrm{~B}$ & $0: 1$ \\
\hline Phocoena phocoena & NE Pacific (US) & Neritic & 2007 & Unknown & $0: 1$ \\
\hline Phocoena spinipinnis & SE Pacific (central Chile) & Neritic & $1998-2002$ & $\mathrm{~S} \& \mathrm{~B}$ & $1: 3$ \\
\hline Cephalorhynchus commersonii & SW Atlantic (Patagonia, Argentina) & Neritic & 2005 & $\mathrm{~F}$ & $0: 1$ \\
\hline Cephalorhynchus eutropia & $\begin{array}{l}\text { SE Pacific (Guaitecas Archipelago, } \\
\text { Northern Patagonia, Chile) }\end{array}$ & Inshore/estuarine & 2007 & $\mathrm{~F}$ & $19: 4^{\mathrm{a}}$ \\
\hline Cephalorhynchus hectori maui & Tasman Sea (North Island, New Zealand) & Inshore & $1997-2003$ & $\mathrm{~S} \& \mathrm{~B}$ & $2: 1$ \\
\hline Delphinus delphis & NE Atlantic (Cascais, Portugal) & Oceanic & 1990 & $\mathrm{~B}$ & $0: 1$ \\
\hline Stenella coeruleoalba & NE Atlantic and North Sea (British Isles) & Oceanic & $2004-2006$ & $\mathrm{~S} \& \mathrm{~B}$ & $3: 1$ \\
\hline Sotalia guianensis & SW Atlantic (Guaraquecaba, Brazil) & Inshore/estuarine & 2007 & $\mathrm{~F}$ & $0: 1$ \\
\hline Lagenorhynchus australis & $\begin{array}{l}\text { SE Pacific (Guaitecas Archipelago, } \\
\text { Northern Patagonia, Chile) }\end{array}$ & Inshore/estuarine & 2007 & $\mathrm{~F}$ & $21: 8^{\mathrm{a}}$ \\
\hline Tursiops truncatus & SE Pacific (Choros Islands, Chile) & Inshore & 1998 & $\mathrm{~F}$ & $0: 1$ \\
\hline
\end{tabular}

behavioural clues (Wells et al. 1980, Goodall et al. 1988, Shane 1990).

Tattoo lesions. Tattoos were identified on the basis of their typical appearance, i.e. irregular, dark gray, black or yellowish marks with a stippled pattern
(Fig. 1). The corporal topography of these marks as well as their number and relative size (small, medium, large and very large) were noted, though not systematically. Light gray, irregular marks surrounded by a black line were considered regressing tattoos
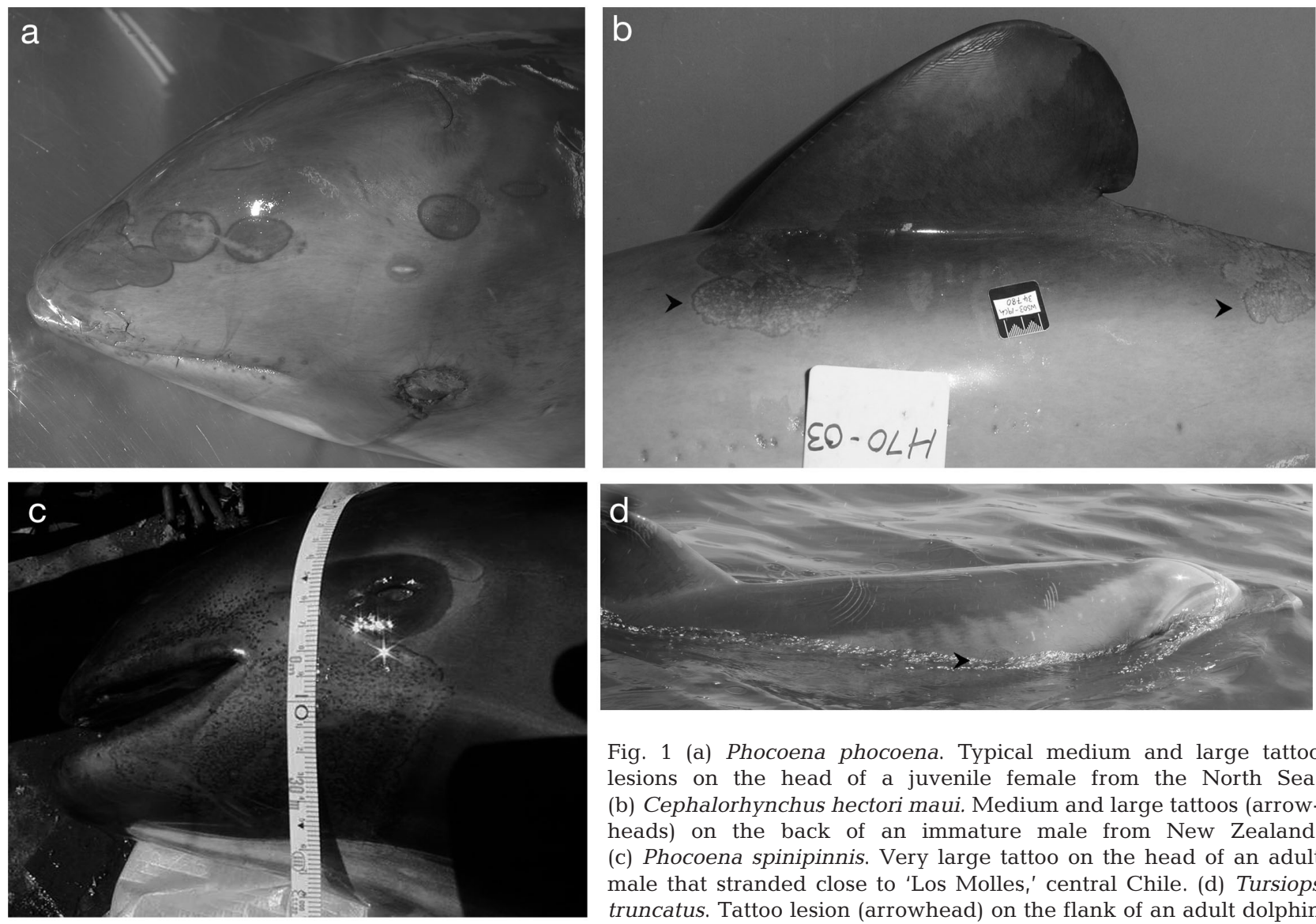

Fig. 1 (a) Phocoena phocoena. Typical medium and large tattoo lesions on the head of a juvenile female from the North Sea. (b) Cephalorhynchus hectori maui. Medium and large tattoos (arrowheads) on the back of an immature male from New Zealand. (c) Phocoena spinipinnis. Very large tattoo on the head of an adult male that stranded close to 'Los Molles,' central Chile. (d) Tursiops truncatus. Tattoo lesion (arrowhead) on the flank of an adult dolphin from Paracas Bay, Peru 

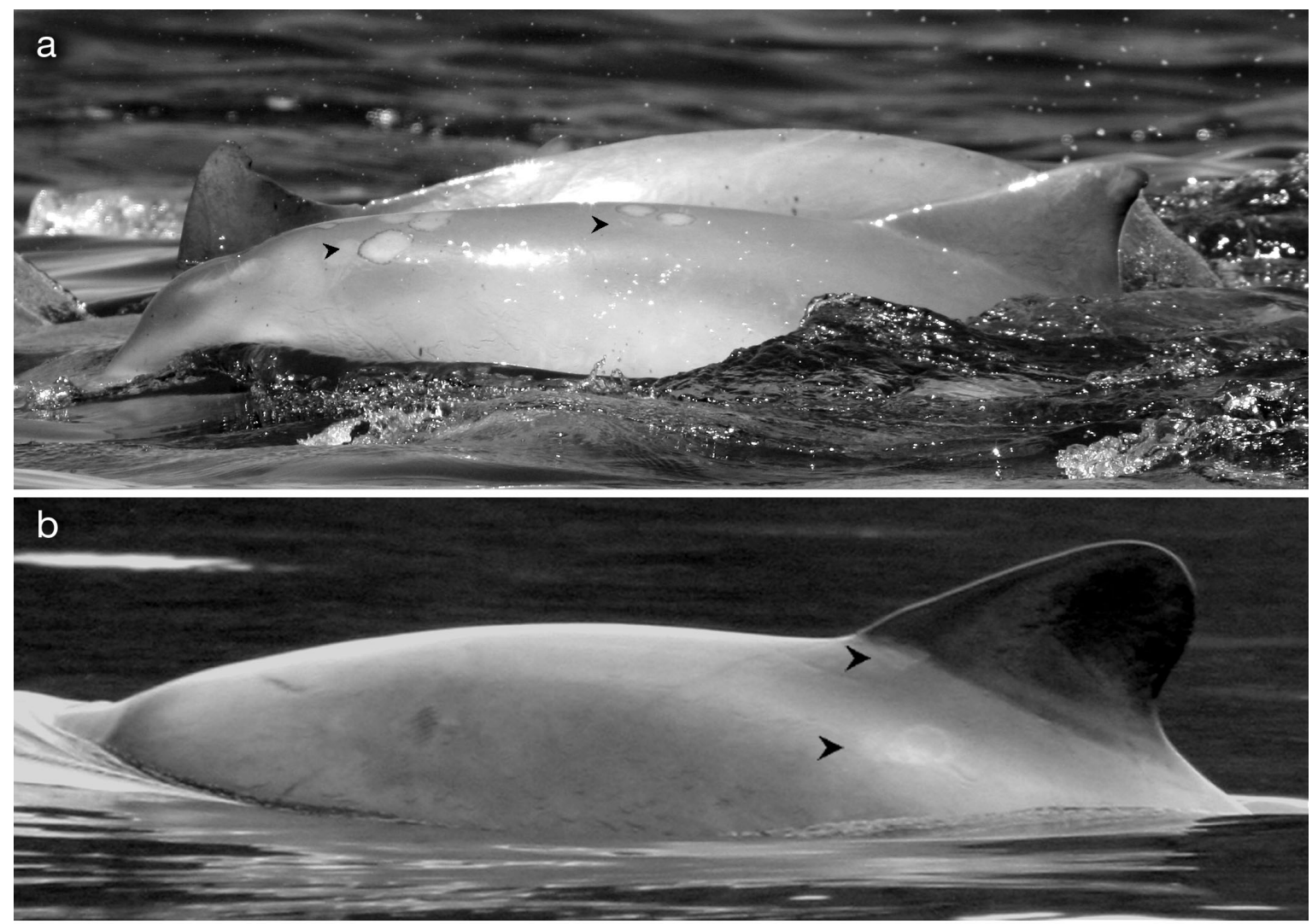

Fig. 2. (a) Sotalia guianensis. Regressing tattoos (arrowheads) on the dorsum of a dolphin from Sepetiba Bay, Brazil. (b) Cephalorhynchus eutropia. Regressing tattoos (arrowheads) on dorsum and dorsal fin of an adult dolphin from Reñihue Fjord, northern Patagonia, Chile

(Fig. 2). Light gray, mostly rounded marks without a dark outline were regarded as healed lesions. To avoid bias, only animals observed by the authors were included. For most images the first author confirmed tattoo lesions. Only active tattoos, including regressing but not healed tattoos, were considered for the statistical analysis. TSD aetiology was confirmed by electron microscopy in Peruvian small cetaceans (Van Bressem et al. 1993, Van Bressem \& Van Waerebeek 1996) and by PCR in harbour porpoises Phocoena phocoena and striped dolphins Stenella coeruleoalba from the British Isles (Pearce et al. 2008). Though investigations on the aetiology of TSD in cetaceans from other ocean provinces could not be carried out, it is likely that it was also caused by poxviruses. Indeed, poxviruses are the only infectious agents consistently observed by electron microscopy or detected by PCR in tattoos from several species of odontocetes (Flom \& Houk 1979, Geraci et al. 1979, Van Bressem et al. 1993, 1999, Bracht et al. 2006).

Geographic distribution. On the basis of the results of this study, published records (Geraci et al. 1979, Bossart et al. 2003, Bracht et al. 2006, Van Bressem et al. 1993, 1999, 2006b, Bearzi et al. 2009) and unpub- lished data archived at CEPEC, we mapped the known distribution of TSD.

Statistical analyses. With the exception of Peale's dolphin Lagenorhynchus australis and Cephalorhynchus eutropia communities from Guaitecas Archipelago, northern Patagonia, Chile, that are still under study, samples with $\mathrm{n} \geq 7$ animals, grouped by species, geographical region and sampling type (free-ranging, stranded and traumatic death) were considered as observational units for the statistical analysis (Table 1). Free-ranging and stranded odontocetes as well as cetaceans that had suffered a traumatic death were treated separately, as they differed in the screening effort for TSD and population representation. Phocoena phocoena from the British Isles was split into a North Sea population and a NE Atlantic population, including specimens from the English Channel and the Irish and Celtic Seas (see Donovan \& Bjørge 1995). Short-beaked common dolphins Delphinus delphis from the British Isles were assumed to belong to a single population (Murphy et al. 2006) (Table 1). As the exact age of specimens was rarely available, 3 age classes were inferred from the correlation between maturity status and standard body length in each sam- 
ple and defined as follows: (1) neonates and young calves until 6 to $9 \mathrm{mo}^{\mathbf{1}}$ (hereafter referred to as calves), which are likely protected by maternal immunity in populations where the virus is endemic; (2) older calves, juveniles and subadults (hereafter referred to as juveniles), which are likely not protected anymore by passive immunity, have not yet acquired active immunity and thus are susceptible to TSD; and (3) sexually mature animals (adults) that may or may not have active immunity against the virus. Geographical variability in infection patterns of TSD was described based on a scatter plot of prevalences in juveniles and adults for each sample (note that calves were not

${ }^{1}$ Phocoena phocoena $<105.5 \mathrm{~cm}$, Mediterranean Stenella coeruleoalba $<120 \mathrm{~cm}$, Cephalorhynchus hectori ssp. $<90 \mathrm{~cm}$, South American Delphinus delphis $<150 \mathrm{~cm}$, Lagenorhynchus obscurus $<140 \mathrm{~cm}$ and $P$. spinipinnis $<130 \mathrm{~cm}$ infected except in 1 case, see Table 3). Sterne's method was used to determine $95 \%$ CIs for prevalence values (Reiczigel 2003).

We investigated the effects of host sex and age class upon the epidemiological patterns of TSD separately. Sampling type may influence TSD detection, arguably the lowest in free-ranging animals, regardless of sex or age. Geography (e.g. spatial autocorrelation), phylogeny (e.g. similarity in host susceptibility) and virus strain/species (e.g. differences in virulence and infectiousness) may have contrasting effects with regard to sexual or age-related differences in cetacean poxvirus infections. We applied Zelen's test to pinpoint samples that deviated from the common pattern and made attempts to account for such deviations (see below). We further examined whether odontocetes that had died in poor health (PH, i.e. starvation, infectious and parasitic diseases) exhibited a higher prevalence of

Table 3. Occurrence of tattoo skin disease in cetaceans, grouped according to age and sex classes. Numbers separated by colons indicate specimens without:with tattoos. Unk.: animals for which the sex and/or age class were unknown. Population sample codes are provided in Table 1

\begin{tabular}{|c|c|c|c|c|c|c|c|c|c|c|}
\hline \multirow{2}{*}{ Sample code } & \multicolumn{3}{|c|}{ - Calf -} & \multicolumn{3}{|c|}{ Juvenile } & \multirow[b]{2}{*}{ Male } & \multirow{2}{*}{$\begin{array}{l}\text { Mature } \\
\text { Female }\end{array}$} & \multirow[b]{2}{*}{ Unk. } & \multirow{2}{*}{ Unk. } \\
\hline & Male & Female & Unk. & Male & Female & Unk. & & & & \\
\hline \multicolumn{11}{|l|}{ Free-ranging } \\
\hline 1f & & & & & & $1: 0$ & & & $79: 0$ & \\
\hline $2 \mathrm{f}$ & & & & & & $5: 5$ & & & $23: 2$ & \\
\hline $3 f$ & & & $4: 0$ & & & $0: 2$ & & & $14: 2$ & $57: 0$ \\
\hline $4 \mathrm{f}$ & & & & & & & & & 195:11 & \\
\hline $5 f$ & & & & & & $3: 0$ & & & $5: 5$ & \\
\hline \multicolumn{11}{|c|}{ Bycatch, T. truncatus attack or other traumas of unknown origin } \\
\hline $1 \mathrm{~b}$ & $1: 0$ & & & $4: 0$ & $3: 0$ & & 11:0 & $6: 0$ & & \\
\hline $2 b$ & & $1: 0$ & & $8: 0$ & $3: 0$ & & & $7: 0$ & & \\
\hline $3 b$ & & $1: 0$ & & $2: 0$ & $1: 1$ & & $4: 0$ & $1: 0$ & & \\
\hline $4 \mathrm{~b}$ & $1: 0$ & $3: 0$ & & $7: 0$ & $7: 0$ & & $2: 0$ & $6: 0$ & & \\
\hline $5 b$ & & & & $4: 0$ & & & $1: 0$ & $3: 0$ & & \\
\hline $6 b$ & & & & $1: 0$ & $3: 0$ & & $5: 0$ & $5: 0$ & & \\
\hline $7 b$ & $1: 0$ & & & $5: 0$ & $1: 1$ & & $5: 0$ & $5: 0$ & & \\
\hline $8 b$ & $7: 0$ & 9:0 & & $16: 20$ & $18: 15$ & & $34: 16$ & $38: 23$ & & \\
\hline $9 b$ & $2: 0$ & $4: 0$ & & $4: 18$ & $4: 5$ & & $4: 20$ & $11: 5$ & & \\
\hline $10 \mathrm{~b}$ & & & & $9: 27$ & $2: 4$ & & $9: 1$ & & & $1: 1$ \\
\hline $11 \mathrm{~b}$ & & & & $0: 3$ & $1: 2$ & & $4: 0$ & $2: 0$ & & \\
\hline $12 \mathrm{~b}$ & $11: 0$ & 11:0 & & $2: 1$ & $1: 0$ & & $1: 0$ & & & $1: 0$ \\
\hline $13 b$ & & & & $24: 0$ & $13: 0$ & & $31: 0$ & $21: 0$ & & $2: 0$ \\
\hline $14 \mathrm{~b}$ & & & & $41: 0$ & 29:0 & & $14: 0$ & $18: 0$ & & $2: 0$ \\
\hline $15 \mathrm{~b}$ & & & & $3: 0$ & $4: 0$ & & & $1: 0$ & & \\
\hline $16 \mathrm{~b}$ & $2: 0$ & 1:0 & & $3: 4$ & $4: 1$ & & $12: 2$ & $5: 1$ & 1:0 & $0: 1$ \\
\hline $17 b$ & & & & $1: 0$ & & & $7: 0$ & & & \\
\hline \multicolumn{11}{|l|}{ Stranded } \\
\hline $1 \mathrm{~s}$ & $5: 0$ & $2: 0$ & & $6: 1$ & $3: 0$ & & $7: 2$ & $2: 1$ & & \\
\hline $2 \mathrm{~s}$ & $6: 0$ & $2: 0$ & & $13: 1$ & $14: 2$ & & $2: 1$ & $4: 1$ & & \\
\hline $3 \mathrm{~s}$ & & & & $5: 0$ & $2: 0$ & & $1: 0$ & $2: 0$ & & $2: 0$ \\
\hline $4 \mathrm{~s}$ & $1: 0$ & & & $1: 0$ & $1: 0$ & & $0: 1$ & $4: 1$ & & \\
\hline $5 \mathrm{~s}$ & $2: 0$ & $4: 1$ & & $8: 1$ & $6: 1$ & & $8: 0$ & 9:0 & & \\
\hline $6 s$ & & & & & $3: 1$ & & $1: 0$ & $2: 0$ & & 1:0 \\
\hline $7 \mathrm{~s}$ & $1: 0$ & $6: 0$ & & $5: 1$ & $1: 1$ & & $5: 1$ & $6: 0$ & & \\
\hline $8 \mathrm{~s}$ & $2: 0$ & & & $1: 0$ & & & & & & \\
\hline
\end{tabular}


TSD than those that had died a traumatic death (TD). This was only possible in Phocoena phocoena and Delphinus delphis from the British Isles (codes 3b, 4b, 7b, $1 \mathrm{~s}, 2 \mathrm{~s}, 4 \mathrm{~s}$, see Table 1), where thorough necropsies had been carried out and the cause of death determined unequivocally. Sparse and unbalanced data precluded the use of a single model including both factors (Table 3). For the same reason multivariate models further controlling for (at least) host phylogeny and spatial (geographical) autocorrelation (see Peres-Neto 2006 and references therein) would have generated highly biased results (see Agresti \& Hartzel 2000). The potential influence of confounding factors, potential interactions between factors, or statistical dependency among observations upon the results obtained are further clarified in the discussion section. We sought general conclusions about the effect of host sex and age upon the likelihood of suffering TSD by combining results from a number of samples. Within this sort of 'metaanalytical' approach, we found it useful to estimate the central tendency and variability in effect sizes across samples rather than simply testing departures from a null hypothesis (Nakagawa \& Cuthill 2007, Thompson 2007, Levine et al. 2008). Accordingly, statistical tests were accompanied by the estimation of the magnitude of effect sizes, and the precision of these estimates.

We selected 2 statistics for effect size, i.e. difference of prevalence (DP) and odds ratio. DP was chosen because (1) it is easily interpretable and (2) it is possible to set confidence limits for DP even when neither of the 2 samples to be compared was infected with TSD (see Agresti \& Min 2001 for details). DPs between sexes were obtained as males minus females. DPs between age classes were obtained as juveniles minus calves, and juveniles minus adults; a positive DP was expected in both comparisons according to Van Bressem \& Van Waerebeek (1996). Exact 95\% CI for DP was set in each sample by inverting a 2-sided unconditional test for difference of proportions (see Agresti \& Min 2001 for details). The odds ratio measures the increase (or decrease) in odds of suffering TSD between selected groups (e.g. males vs. females). It was selected because it is one of the most important comparative risk measurements in epidemiology (Kahn \& Sempos 1989). More significantly the odds ratio forms the basis of Mantel-Haenszel's test, which allows examining significant departures from a ratio of 1 using samples as a stratifying variable. The use of a single test allows a more precise estimate of a general sex or age class effect, and greatly enhances statistical power particularly when sample sizes are small (Agresti \& Hartzel 2000). However, Mantel-Haenszel's test is meaningful only when odds ratios do not differ among samples. We used Zelen's exact test for homogeneity of odds ratios as it performs well for unbalanced designs with sparse data (Reis et al. 1999). Assessment of homogeneity also allowed identifying those samples that departed from the common odds ratio pattern. Therefore, the test could be used indirectly to explore confounding effects of other factors that were not modeled (e.g. geography, phylogeny or sample type). For the group of samples for which homogeneity held, we calculated the $95 \%$ CI for the common odds ratio and carried out exact Mantel-Haenszel's tests for departure from 1 (Agresti \& Hartzel 2000).

The software Quantitative Parasitology v. 3.0 (Reiczigel \& Rósza 2005) was used for the calculation of confidence intervals for prevalence, and Statxact v.8 for the remaining statistical analyses. Exact tests (permutational p-values) were always preferred because sample sizes were small, sparse and unbalanced. However, when calculations were very time-consuming, a Monte Carlo estimate of p-values based on 100000 random samples from the reference set was used.

\section{RESULTS}

\section{Characteristics of the disease}

Tattoos were typical in all affected species (Fig. 1). In dolphins and porpoises for which tattoo size was recorded, it ranged from $10 \times 7$ to $245 \times 245 \mathrm{~mm}$. Very large lesions (>150 $\mathrm{mm}$ in at least 1 dimension) were seen in adults of samples 2f, 8b, 9b (Table 1), a Phocoena phocoena from the NE Atlantic (not included in statistics) and a P. spinipinnis from central Chile (Fig. 1c). Tattoo number per animal ranged from 1 to more than 50 . They were distributed on the flanks, back, belly, throat, tailstock, head, dorsal fin and flippers. A preferential distribution was observed in Lagenorhynchus obscurus, $P$. spinipinnis and long-beaked common dolphins Delphinus capensis from Peru (Van Bressem \& Van Waerebeek 1996). In P. spinipinnis from Peru and Chile tattoos were more frequently seen on the head. Similarly, in $P$. phocoena these lesions were often seen on the head $(55.5 \%)$ and flanks $(55.5 \%)(\mathrm{n}=9)$. Regressing tattoos and tattoo remains were observed in most species examined in this study (Fig. 2).

\section{Geographical pattern}

Compiled TSD records from the Americas, Europe and New Zealand are presented in Fig. 3. The disease is widespread and affects various cetacean species from different habitats. The most southerly and northerly TSD records were detected in free-ranging Lagenorhynchus australis and Cephalorhynchus eutropia from the Guaitecas Archipelago (435' S, 

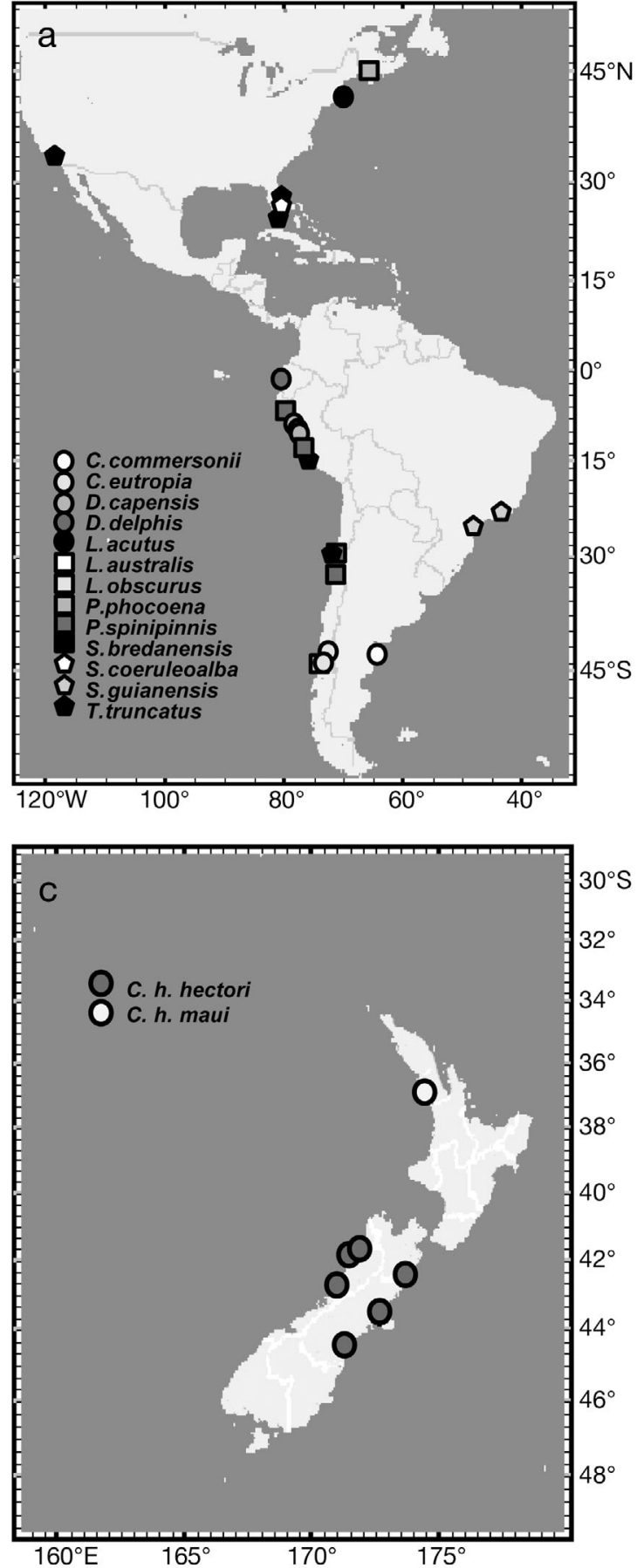

$73^{\circ} 45^{\prime} \mathrm{W}$ ), Chile (Fig. 3a), and in a Phocoena phocoena stranded on the coast of Northumberland $\left(55^{\circ} 07^{\prime} \mathrm{N}\right.$ $1^{\circ} 30^{\prime} \mathrm{W}$ ), UK (Fig. 3b), respectively. During this study TSD was not observed in the following samples: freeranging Tursiops truncatus from the northern Adriatic (1f), bycaught Delphinus capensis (1b) and IndoPacific bottlenose dolphins T. aduncus (2b) from South Africa; bycaught Sotalia guianensis (13b), franciscana Pontoporia blainvillei (14b) and Atlantic spotted dol-

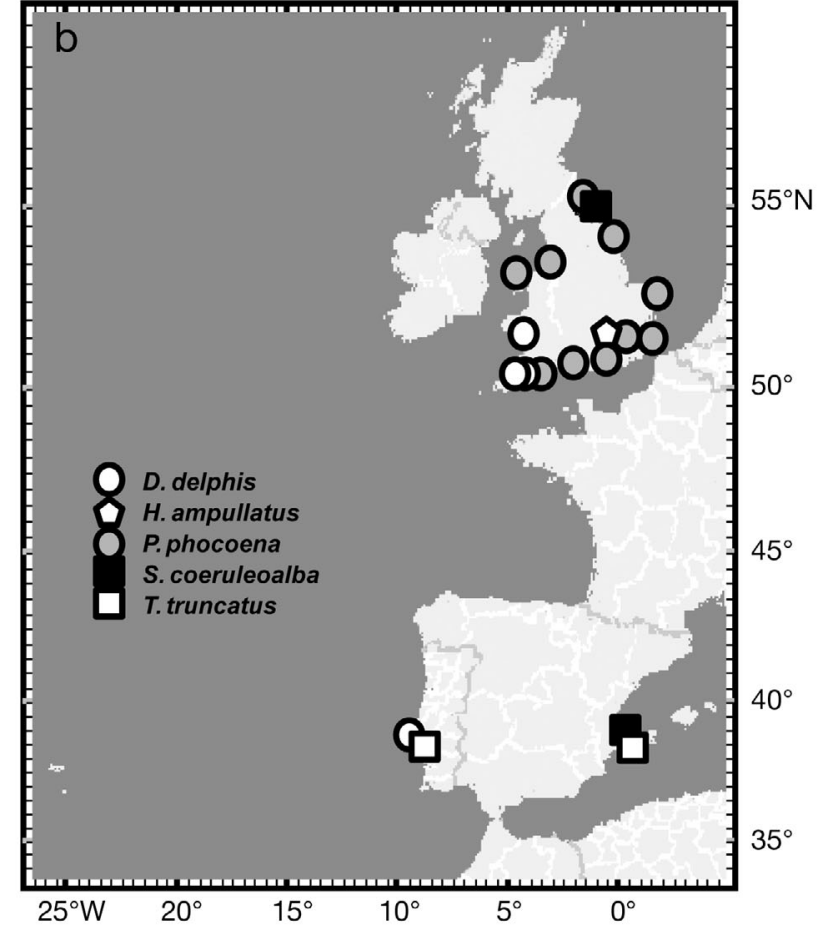

Fig. 3. (a) Distribution of tattoo skin disease in Delphinidae and Phocoenidae from the Americas, including data presented in this paper, unpublished data from the Peruvian Centre for Cetacean Research and published data (Geraci et al. 1979, Bossart et al. 2003, Bracht et al. 2006, Van Bressem et al. 1993, 1999, 2006b, Bearzi et al. 2009). Steno bredanensis at the same location as T. truncatus and a $S$. coeruleoalba from Florida. (b) Distribution of tattoo skin disease in odontocetes from European waters. (c) Cephalorhynchus hectori hectori and C. h. maui. Distribution of tattoo skin disease in dolphins from New Zealand. Full species names given in Tables $1 \& 2$

phin Stenella frontalis (15b) from northern Rio de Janeiro, Brazil; stranded and bycaught $P$. phocoena from the German North (3s) and Baltic Seas (5b) and Greenland (6b) (Table 1). However it was present in free-ranging $S$. guianensis from southern Rio de Janeiro (4f) and in P. phocoena from the British part of the North Sea $(1 \mathrm{~s}, 3 \mathrm{~b})$. In both cases, sample sizes seemed large enough to rule out that inconsistencies were caused by false negatives. In the case of $S$. guia- 
nensis these observations may be related to the origin of the samples. Indeed, the $S$. guianensis from northern and southern Rio de Janeiro likely belong to 2 distinct communities which may not intermingle (A. P. di Beneditto \& L. Flach pers. obs.) and thus may not share the same micro-organisms. The origin of the differences in prevalence between North Sea $P$. phocoena collected along the German and British coasts remains unknown. In many samples, the $95 \%$ CIs for prevalence were wide due to small sample size. No clear patterns related to geography and host phylogeny were observed, except that TSD prevalence in all juveniles as well as in adult L. obscurus and Phocoena spinipinnis tended to be higher in samples from Peru (Fig. 4).

\section{Sex}

Values of DP between males and females of each sample were scattered around 0 and the $95 \% \mathrm{CI}$ included 0, except in male Phocoena spinipinnis from Peru (sample 9b), which exhibited a significantly higher prevalence than females (Fig. 5, Table 3). Note that the precision of DP estimates was generally low because of small sample sizes (Fig. 5).

The hypothesis of a homogeneous odds ratio for all samples could not be rejected (Zelen's exact test, $\mathrm{n}=$ $14, \mathrm{p}=0.076$ ), nor could the hypothesis that the common odds ratio did not differ from 1 (exact $p=0.095$ ) with a point estimate of 1.44 (95\% CI: 0.96 to 2.16). However, when sample $9 \mathrm{~b}$ was removed, evidence that the null hypothesis of homogeneity should not be rejected was stronger (exact $p=0.963$ ), and the common odds ratio was far closer to 1 with a point estimate of 1.027 (95\% CI: 0.665 to 1.60). We conclude that there is no evidence that sex influences TSD prevalence, except in the case of $P$. spinipinnis from Peru (see sample 9b in Fig. 5).

\section{Age class}

With the exception of a single specimen of Stenella coeruleoalba from the Mediterranean Sea, TSD was not detected in calves from any species for which this age class was represented (Table 3). Accordingly, a positive value of DP between juveniles and calves was generally observed (Fig. 6a). The hypothesis of homogeneous odds ratio for all samples could not be rejected (Zelen test $=$ $0.019, \mathrm{n}=11$, exact $\mathrm{p}=0.066$ ) and the common odds ratio was 48.74 (95\% CI: 8.78 to 1039.0 ), departing very significantly from 1 (Mantel-Haenszel test, exact 1-tailed $\mathrm{p}<0.0001)$. In summary, there is a general pattern of increase of TSD infections in juveniles compared to calves.
A positive trend was also observed in DP values of juveniles vs. adults (Figs. 4 \& 6b), although in the 3 samples of stranded cetaceans from the British Isles $(1 \mathrm{~s}, 2 \mathrm{~s}$ and $4 \mathrm{~s})$ and the sample of free-ranging Cephalorhynchus eutropia from southern Chile (5f),

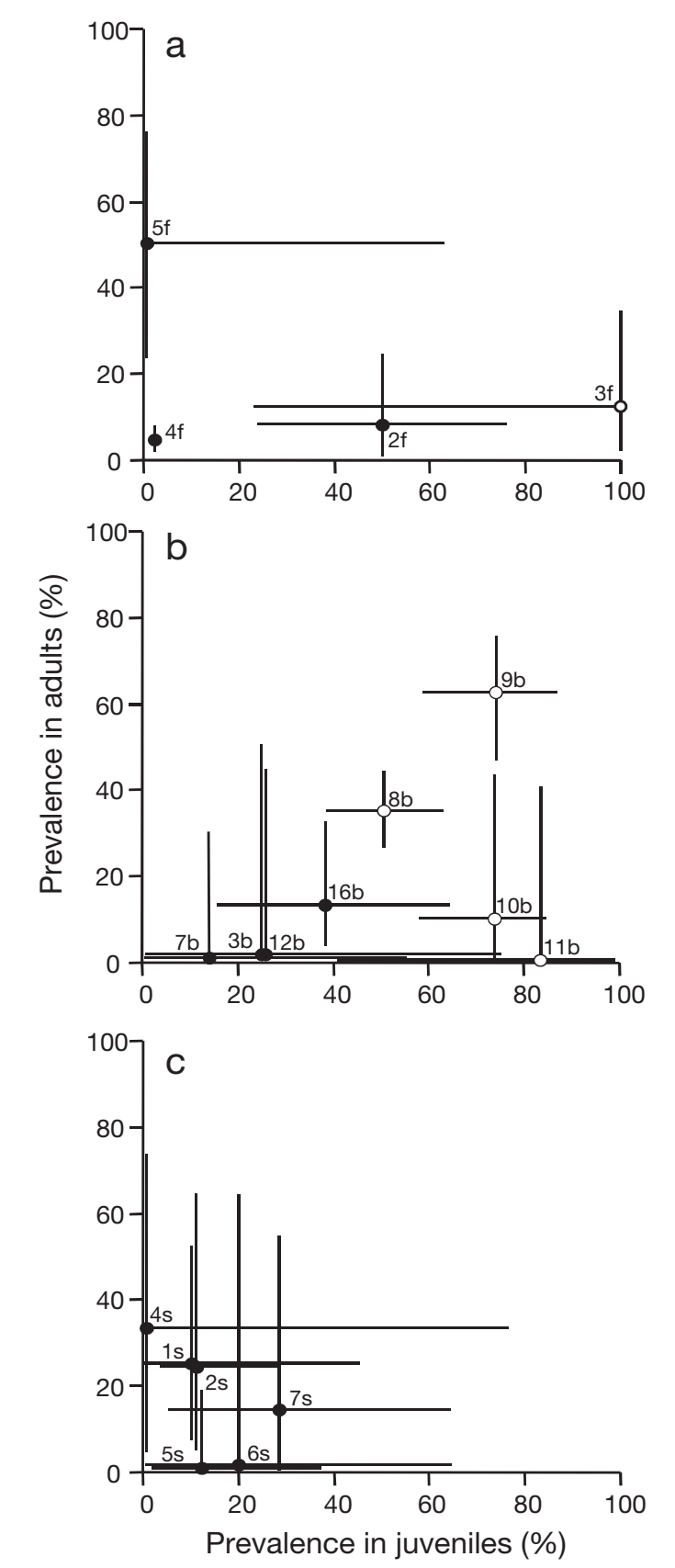

Fig. 4. Scatter-plot of prevalence (in percentage) of tattoo skin disease (TSD) in juvenile and adult cetaceans in samples from different geographical regions with at least 1 positive case. (a) Free-ranging dolphins. Note that the $x$ coordinate for sample $4 \mathrm{f}$ is arbitrary as juveniles were not present in this sample (see Table 3). (b) Cetaceans that died a traumatic death. (c) Stranded odontocetes. Bars represent 95\% CIs. Sample codes as in Table 1 


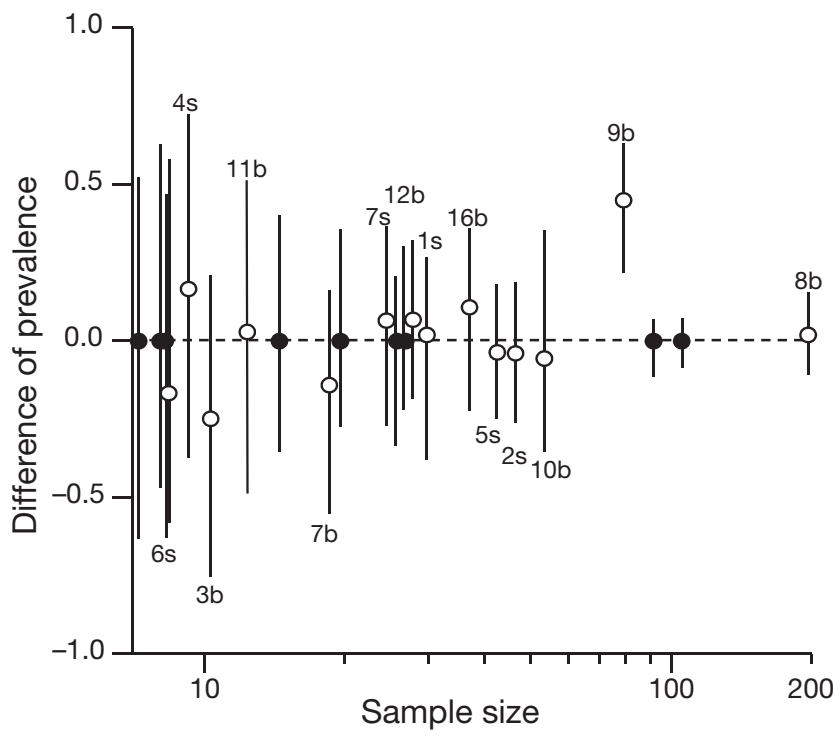

Fig. 5. Values of difference of prevalence (males minus females) of tattoo skin disease (TSD) in samples of cetaceans from different geographical regions. O: samples with at least a positive case for TSD; 0 : samples in which TSD was not detected. Bars represent the $95 \%$ CIs. Sample codes as in Table 1

the prevalence of adults exceeded that of juveniles (Table 3 ; Fig. 6b). Odds ratios were not homogeneous across samples (Zelen statistic $=0.430, \mathrm{n}=17$, Monte Carlo $\mathrm{p}=0.0014)$. When these 4 samples were removed, rejection of the null hypothesis of homogeneity was not accepted (Zelen statistic $<0.001, \mathrm{n}=13$, Monte Carlo $\mathrm{p}=0.061$ ). In this case the common odds ratio was 3.41 (95\% CI: 2.21 to 5.29), with juveniles having significantly higher odds of suffering TSD (exact Mantel-Haenszel test, exact 1 -tailed $\mathrm{p}<0.0001)$. Thus, there is a tendency for juveniles to have greater probability of TSD than adults, but this tendency can be inverted in some cetacean populations.

\section{Health status}

We examined whether the health status could influence the probability of suffering from TSD by comparing animals from waters off the British Isles that died PH vs. TD. Samples comprised of 23 Delphinus delphis (negative:positive for TSD: PH 3:2; TD 17:1); 68 Phocoena phocoena from the NE Atlantic (PH 37:5; TD 26:0), 36 P. phocoena from the North Sea (PH 22:4; TD 9:1) and 2 Stenella coeruleoalba (PH 0:1 and TD 1:0) that were thoroughly necropsied. The difference in prevalence of TSD in animals that died PH vs. TD was always positive, ranging from 0.064 to 1 . Odds ratios were homogeneous across samples (Zelen's statistic: $0.193, \mathrm{n}=4, \mathrm{p}=$

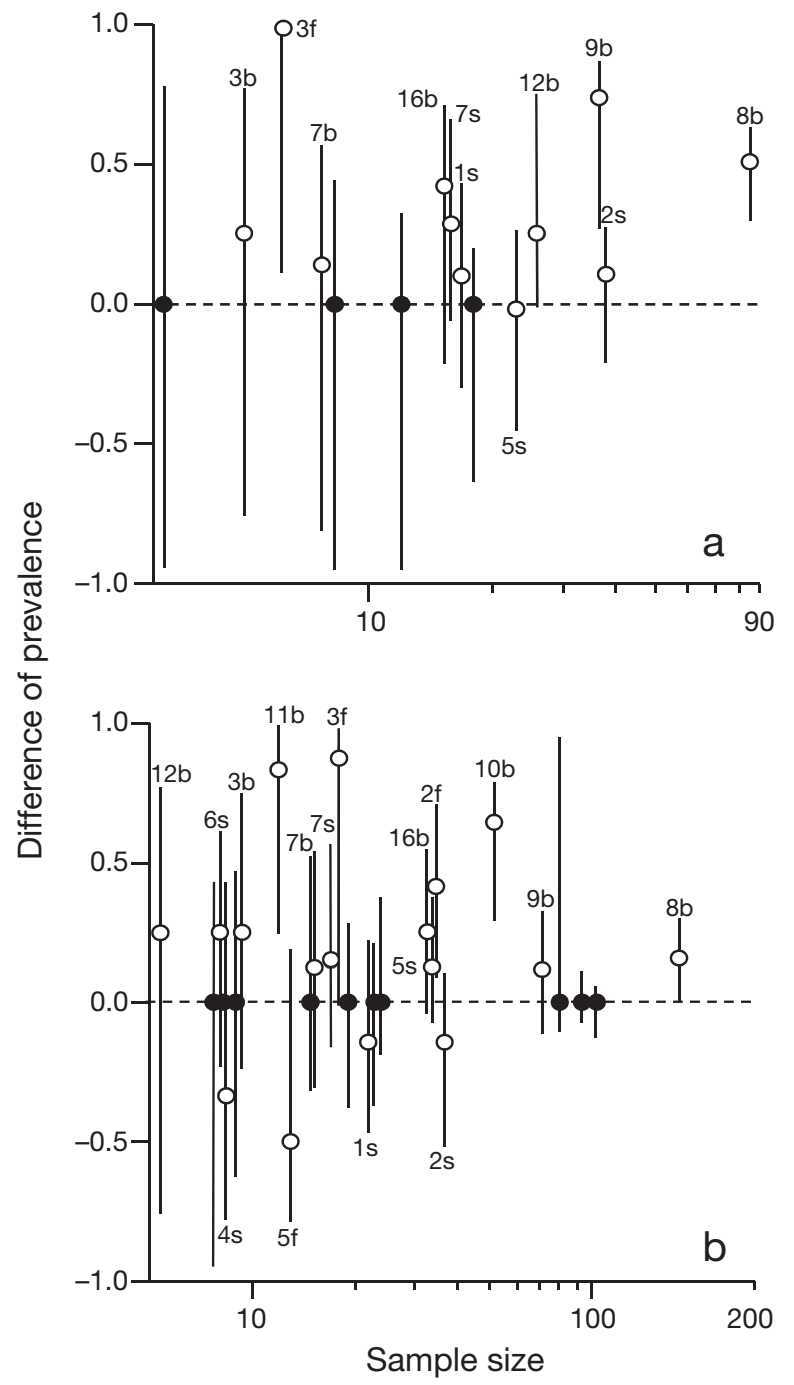

Fig. 6. Values of difference in prevalence of tattoo skin disease (TSD) in samples of cetaceans from different geographical regions. (a) Juveniles minus calves. (b) Juveniles minus adults. O: samples with at least 1 positive case for TSD; -: samples in which TSD was not detected. Bars represent the $95 \%$ CIs. Sample codes as in Table 1

$0.365)$ and the common odds ratio $(7.16,95 \% \mathrm{CI}$ : 1.46 to 57.5 ) departed significantly from 1 (exact 1 tailed $\mathrm{p}=0.011$ ). Interestingly, the odds ratio of TSD infections between juveniles and adults differed significantly (Zelen's test, $\mathrm{p}<0.01$ ) in TD vs. PH samples (TD: juvenile 24:2; adult 23:0; $\mathrm{PH}$ : juvenile $31: 5$; adult 18:7). We conclude that cetaceans in the $\mathrm{PH}$ group exhibited a greater prevalence of TSD, and that prevalence remained high in adults as compared with cetaceans that died a traumatic death. Four of the 5 positive adult $P$. phocoena also had a high number of tattoos and 1 of the 2 positive adult $D$. delphis showed a large $(110 \mathrm{~mm})$ tattoo. 


\section{DISCUSSION}

During this study we examined the prevalence of TSD in several cetacean species and populations (Tables 1 \& 2, Fig. 3). The disease was encountered in 13 species and in 2 subspecies from 5 water bodies (Tables 2 \& 3): the Atlantic and Pacific Oceans as well as the North, Mediterranean and Tasman Seas. Our data only confidently suggest that in some ocean provinces TSD is frequent and affects several sympatric, odontocete species (e.g. off Peru and around the British Isles) whereas in other regions TSD infections occur less frequently or remain undetected in most species examined (e.g. SW Atlantic). Peruvian coastal waters appear to represent a high-risk area for TSD. Prevalence was remarkably high in both delphinids and phocoenids, especially in juveniles. Although no abundance estimates exist, frequent sightings of large to very large groups (high 100s to 1000s of individuals per group, K. Van Waerebeek pers. obs.) and apparently sustained annual bycatches of several thousand specimens of each species over many years (e.g. Van Waerebeek \& Reyes 1994, Alfaro-Shigueto et al. 2008) hint that Peruvian populations of Lagenorhynchus obscurus, Delphinus capensis, offshore Tursiops truncatus and Phocoena spinipinnis are very large. High densities of individuals are thought to facilitate virus maintenance and continued infection of juveniles. The poxviruses circulating in Peruvian populations may also be more infectious than those present in other ocean provinces. However, they have not yet been characterized, preventing further discussion. Environmental stressors such as fishery interactions and pollution may also play a role in lowering the immune response (Clark et al. 2006, Hall et al. 2006). There was no obvious relationship between epidemiological values and geography and host phylogeny. However, as TSD screening effort and host sample size were strongly uneven among samples, this should be further studied before any definitive conclusion can be drawn. The occurrence of TSD in several ocean provinces and its holoendemic pattern in many populations further suggest that cetacean poxviruses have been infecting cetaceans for a long time (Bracht 2005, Pearce et al. 2008).

We investigated the influence of host sex and age upon the prevalence of TSD in several species and ocean provinces after verifying that the general pattern was not significantly confounded by sample type, geography, phylogeny or interaction between host sex and age. With the exception of Peruvian Phocoena spinipinnis, prevalence of the disease was similar in both sexes in all species examined. We discerned a general pattern of an increase of TSD in juveniles compared to calves, likely because juveniles had lost maternal humoral immunity and become fully receptive to the virus, as previously suggested (Van Bressem \& Van Waerebeek 1996). Juveniles revealed a significantly higher probability of having TSD than adults in most samples, with the exception of cetaceans in poor health from the British Isles and Cephalorhynchus eutropia from southern Chile. A high percentage of adults likely had developed active immunity following infection and were protected against re-infection. This typical holoendemic pattern appeared to be inverted in poor health odontocetes as demonstrated in Delphinus delphis and P. phocoena from the British Isles, where prevalence was significantly higher in adults than in juveniles. Geraci et al. (1979) also reported that in captive dolphins the development of TSD was linked to general poor health. High exposure to polychlorinated biphenyls (PCBs) was previously shown to increase the risk of mortality from infectious diseases in $P$. phocoena from the British Isles, presumably because of their immunosuppressive effects (Jepson et al. 1999, 2005, Hall et al. 2006). It is possible that a high prevalence of TSD in adults reflects a depressed immune system, but this should be further studied. The presence of very large tattoos in some adult small cetaceans from the SE Pacific, NE Atlantic and Sado Estuary evokes 'progressive vaccinia', a life-threatening complication of smallpox vaccination in humans with immunological deficiencies, and similarly suggests an impaired immune response (Van Bressem \& Van Waerebeek 1996, Van Bressem et al. 2003). An adult $P$. spinipinnis from central Chile (Fig. 1c) presenting many tattoos, one of them very large, was also diagnosed with pneumonia.

In summary, this is the first time that a clear, general age-related epidemiological pattern is reported for TSD. Departure from this pattern, i.e. TSD prevalence remaining high in adults, occurred in some cetacean populations and, at least in 1 region, was associated with individuals that had died in poor health. It is thus possible that the epidemiological pattern of TSD is an indicator of cetacean population health. Future research should seek to correlate the presence, number and size of tattoo lesions with quantitative data on contaminant loads, including PCB congeners amongst others. Inshore and neritic cetaceans living in a contaminated environment, stressed by fisheries interactions and disturbance from dense shipping may be physiologically challenged to mount an adequate immune response against infectious agents.

Acknowledgements. We kindly acknowledge C. Agusti and P. Gozalbes for their help with processing data collected in Mediterranean cetaceans. We thank A. Garcia-Godos, K. Onton, L. Chávez-Lisambart and J. Alfaro-Shigueto for their assistance in collecting TSD data in Peruvian small cetaceans, 
V. Altayó, D. Durandin and F, Filipponi for supporting the cetacean stranding program of the CMMR Leviathan, Dr. R. J. Monies for sending us the image of a giant tattoo in Phocoena phocoena, Dr. M. Sequeira for the photo of an infected Delphinus delphis from Portugal, Dr. E. Crespo for images of tattoo lesions in Cephalorhynchus commersonii, Dr. M.P. HeideJorgensen for allowing us to examine the $P$. phocoena collected by his institute, Dr. G. Pearce for the PCR data and J. Samaniego for collecting the specimens of $D$. delphis in Ecuador. G. Jones, M. Bando, N. Gibbs, and A. Hutt assisted with examination of Hector's dolphins. Necropsies of UKstranded cetaceans were funded under contract to the UK Government (Department for Environment, Food and Rural Affairs) as part of its commitment to a number of international conservation agreements. This study was supported by the Cetacean Society International, the Whale and Dolphin Conservation Society, the 'Fundação para a Ciência e Tecnologia' from the Portuguese Ministry of Science and Technology, the 'Reserva Natural do Estuário do Sado', the 'Conselleria de Medio Ambiente de la Generalitat Valenciana', the 'Ministerio de Medio Ambiente', Spain and the Federal Ministry for Education and Research, Germany. CEPEC field research was supported by grants from IFAW, the Gesellschaft zum Schutz der Meeressäugetiere, Leopold III Fund for Nature Research and Conservation, IUCN Cetacean Specialist Group, the Chicago Zoological Society and the Department of Conservation, Te Papa Atawhai, Wellington, New Zealand. The field work of 'Projeto Boto Cinza' was fully supported by Companhia Vale do Rio Doce. The CEO and staff of the Natal Sharks Board are thanked for allowing access to South African specimens.

\section{LITERATURE CITED}

Agresti A, Hartzel J (2000) Strategies for comparing treatments on a binary response with multi-centre data. Stat Med 19:1115-1139

Agresti A, Min Y (2001) On small-sample confidence intervals for parameters in discrete distributions. Biometrics 57 : 963-971

Alfaro-Shigueto J, Mangel JC, Van Waerebeek K (2008) Small cetacean captures and CPUE estimates in artisanal fisheries operating from a port in northern Peru, 2005-2007. Doc SC/60/SM19 presented to IWC Scientific Committee Meeting, Santiago, June 2008. International Whaling Commission, Cambridge

Bearzi M, Rapoport S, Chau J, Saylan Ch (2009) Skin lesions and physical deformities of coastal and offshore common bottlenose dolphins (Tursiops truncatus) in Santa Monica Bay and adjacent areas, California. Ambio 38:66-71

Bossart GD, Meisner R, Varela R, Mazzoil M and others (2003) Pathologic findings in stranded Atlantic bottlenose dolphins (Tursiops truncatus) from the Indian River Lagoon, Florida. Fla Sci 66:226-238

Bracht AJ (2005) Detection and molecular characterization of cetacean and pinniped poxviruses associated with cutaneous lesions. MS thesis, University of Florida, Gainesville, FL

Bracht AJ, Brudek RL, Ewing RY, Manire CA and others (2006) Genetic identification of novel poxviruses of cetaceans and pinnipeds. Arch Virol 151:423-438

Calzada N (1995) Biología del delfín listado (Stenella coeruleoalba) del Mediterraneo occidental. PhD thesis, University of Barcelona

Chávez-Lisambart L (1998) Age determination, growth, and gonadal maturation as reproductive paprameters of dusky dolphin Lagenorhynchus obscurus (Gray 1828) from Peruvian waters. $\mathrm{PhD}$ thesis, University of Hamburg

Clark LS, Cowan DF, Pfeiffer DC (2006) Morphological changes in the Atlantic bottlenose dolphin (Tursiops truncatus) adrenal gland associated with chronic stress. J Comp Pathol 135:208-216

Collet A, Saint Girons H (1984) Preliminary study of the male reproductive cycle in common dolphins, Delphinus delphis, in the Eastern North Atlantic. Rep Int Whaling Comm Spec Issue 6:355-360

Donovan GP, Bjørge A (1995) Harbour porpoises in the North Atlantic: edited extract from the report of the IWC Scientific Committee, Dublin 1995. Rep Int Whal Comm Spec Issue 16:4-25

Duignan PJ, Gibbs NJ, Jones GW (2003) Autopsy of cetaceans incidentally caught in fishing operations 1997/98, 1999/2000, and 2000/01. DOC Science Internal Series No. 119. New Zealand Department of Conservation, Wellington

> Flach L, Flach P, Chiarello AG (2008) Aspects of behavioral ecology of Sotalia guianensis in Sepetiba Bay, southeast Brazil. Mar Mamm Sci 24:503-515

> Flom JO, Houk EJ (1979) Morphologic evidence of poxvirus in 'tattoo' lesions from captive bottlenosed dolphins. J Wildl Dis 15:593-596

Genov T, Kotnjek P, Lesjak J, Hace A, Fortuna CM (2008) Bottlenose dolphins (Tursiops truncatus) in Slovenian and adjacent waters (northern Adriatic Sea). Ann Ser Hist Nat 18:227-244

> Geraci JR, Hicks BD, St Aubin DJ (1979) Dolphin pox: a skin disease of cetaceans. Can J Comp Med 43:399-404

Goodall RNP, Norris KW, Galeazzi AR, Oporto JA, Cameron IS (1988) On the Chilean dolphin, Cephalorhynchus eutropia (Gray 1846). In: Brownell RL Jr, Donovan GP (eds) The biology of the genus Cephalorhynchus. International Whaling Commission, Cambridge

- Hall AJ, Hugunin K, Deaville R, Law RJ, Allchin CR, Jepson P (2006) The risk of infection from polychlorinated biphenyl exposure in the harbor porpoise (Phocoena phocoena): a case-control approach. Environ Health Perspect 114: 704-711

Hohn A, Scott MD, Wells RS, Sweeney JC, Irvine AB (1989) Growth layers in teeth from known age, free-ranging bottlenose dolphins. Mar Mamm Sci 5:315-342

> Jepson PD, Bennett PM, Allchin CR, Law RJ and others (1999) Investigating potential associations between chronic exposure to polychlorinated biphenyls and infectious disease mortality in harbour porpoises from England and Wales. Sci Total Environ 243-244:339-348

Jepson PD, Bennett PM, Deaville R, Allchin CR, Baker JR, Law RJ (2005) Relationships between polychlorinated biphenyls and health status in harbor porpoises (Phocoena phocoena) stranded in the United Kingdom. Environ Toxicol Chem 24:238-248

Kahn HA, Sempos CT (1989) Statistical methods in epidemiology. Oxford University Press, New York

> Levine TR, Weber R, Hullett CR, Park HS (2008) A communication researcher's guide to null hypothesis significance testing and alternatives. Hum Commun Res 34: 188-209

Lockyer C (1995) Investigation of aspects of the life history of the harbour porpoise, Phocoena phocoena, in British waters. Rep Int Whal Comm Spec Issue 16:189-197

> Murphy S, Herman JS, Pierce GJ, Rogan E, Kitchener AC (2006) Taxonomic status and geographical cranial variation of common dolphins (Delphinus) in the eastern north Atlantic. Mar Mamm Sci 22:573-599 
Nakagawa S, Cuthill IC (2007) Effect size, confidence interval and statistical significance: a practical guide for biologists. Biol Rev Camb Philos Soc 82:591-605

Pearce G, Blacklaws BA, Gajda AM, Jepson P, Deaville R, Van Bressem MF (2008) Molecular identification and phylogenetic relationships in poxviruses from cetacean skin lesions. In: Pierce GJ, Philips E, Lick R (eds) 2008 Proceedings of the European Cetacean Society, Egmond Aan Zee, The Netherlands, 10-12 March 2008

Peddemors VM (1999) Delphinids of southern Africa: a review of their distribution, status and life history. J Cet Res 1: $157-165$

Peres-Neto PR (2006) A unified strategy for estimating and controlling spatial, temporal and phylogenetic autocorrelation in ecological models. Oecologia Brasiliensis 10: 105-119

Perrin WF, Myrick AC Jr (eds) (1980) Age determination of toothed whales and sirenians. Rep Int Whal Comm Spec Issue 3:97-133

Reiczigel J (2003) Confidence intervals for the binomial parameter: some new considerations. Stat Med 22:611-621

Reiczigel J, Rózsa L (2005) Quantitative parasitology 3.0. Budapest. www.zoologia.hu/qp/qp.html

Reis IM, Hirji KF, Afifi AA (1999) Exact and asymptotic tests for homogeneity in several $2 \times 2$ tables. Stat Med 18: 893-906

Reyes JC, Van Waerebeek K (1995) Aspects of the biology of Burmeister's porpoise from Peru. Rep Int Whal Comm Spec Issue 16:349-364

Reyes JC, Echegaray M, De Paz N (2002) Distribución, comportamiento y conservación de cetáceos en el área Pisco Paracas. In: Mendo J, Wolff M (eds) Memorias I Jornada Científica Reserva Nacional de Paracas. Universidad Nacional Agraria, Lima, p 136-144

Shane SH (1990) Behavior and ecology of the bottlenose dolphin at Sanibel Island, Florida. In: Leatherwood S, Reeves RR (eds) The bottlenose dolphin. Academic Press, San Diego, CA, p 245-265

Slooten E (1991) Age, growth and reproduction in Hector's dolphins. Can J Zool 69:1689-1700

Smith AW, Skilling DE, Ridgway SH (1983) Calicivirusinduced vesicular disease in cetaceans and probable interspecies transmission. JAVMA 11:1223-1225

Thompson B (2007) Effect sizes, confidence intervals, and

Editorial responsibility: Michael Moore,

Woods Hole, Massachusetts, USA confidence intervals for effect sizes. Psychol Schools 44:423-432

Van Bressem MF, Van Waerebeek K (1996) Epidemiology of poxvirus in small cetaceans from the Eastern South Pacific. Mar Mamm Sci 12:371-382

Van Bressem MF, Van Waerebeek K, Reyes JC, Dekegel D, Pastoret PP (1993) Evidence of poxvirus in dusky dolphin (Lagenorhynchus obscurus) and Burmeister's porpoise (Phocoena spinipinnis) from coastal Peru. J Wildl Dis 29:109-113

> Van Bressem MF, Van Waerebeek K, Raga JA (1999) A review of virus infections of cetaceans and the potential impact of morbilliviruses, poxviruses and papillomaviruses on host population dynamics. Dis Aquat Org 38:53-65

Van Bressem MF, Gaspar R, Aznar FJ (2003) Epidemiology of tattoo skin disease in bottlenose dolphins Tursiops truncatus from the Sado estuary, Portugal. Dis Aquat Org 56: 171-179

Van Bressem MF, Van Waerebeek K, Bennett M (2006a) Orthopoxvirus neutralising antibodies in small cetaceans from the Southeast Pacific. Lat Am J Aquat Mamm (LAJAM) 5:49-54

Van Bressem MF, Van Waerebeek K, Montes D, Kennedy S and others (2006b) Diseases, lesions and malformations in the long-beaked common dolphin Delphinus capensis from the Southeast Pacific. Dis Aquat Org 68:149-165

Van Waerebeek K (1992) Population identity and general biology of the dusky dolphin Lagenorhynchus obscurus (Gray, 1828) in the Southeast Pacific. PhD thesis, University of Amsterdam

Van Waerebeek K, Reyes JC (1994) Post-ban small cetacean takes off Peru: a review. Rep Int Whal Comm Spec Issue 15:503-519

Viddi FA, Van Bressem MF, Bello M, Lescrauwaet AK (2005) First records of skin lesions in coastal dolphins off southern Chile. Abstracts: 16th Biennial Conference on the Biology of Marine Mammals, 12-16 December 2005, San Diego, CA, p 292-293

Wells RS, Irvine AB, Scott MD (1980) The social ecology of inshore odontocetes. In: Herman LM (ed) Cetacean behavior: mechanisms and functions. John Wiley \& Sons, New York

Würsig B, Jefferson TA (1990) Methods of photo-identification for small cetaceans. Rep Int Whal Comm Spec Issue 12: $42-43$

Submitted: March 4, 2008; Accepted: April 27, 2009

Proofs received from author(s): June 27, 2009 